DOI: http://doi.org/10.31617/k.knute.2019-04-12.25

Власенко І.В., д. е. н., проф. Вінницький торговельно-економічний інститут КНТЕУ м. Вінниця, Україна

\title{
РОЗВИТОК ДИТЯЧОГО ТА ЮНАЦЬКОГО ТУРИЗМУ В УКРАЇ̈I
}

Одним із найважливіших завдань держави $є$ виховання здорового підростаючого покоління, забезпечення його повноцінного духовного, інтелектуального та фізичного розвитку. Успішне виконання цього завдання великою мірою може бути вирішено за рахунок розвитку спортивно-оздоровчого дитячо-юнацького туризму. Враховуючи, що сучасне молоде покоління велику частку вільного часу, не кажучи вже про навчальний час, проводить сидячи за комп'ютером, планшетом, телевізором, на заняттях 3 репетитором, необхідність у впровадженні активного відпочинку стає актуальною як ніколи. Це важливо не лише для тимчасової зміни активності, але й у довгостроковій перспективі для формування здорового способу життя, прищеплення інтересу до активних занять спортом, творчості, живого спілкування, любові до природи, жаги до постійного розвитку, самовдосконалення, пізнання нового.

Проблеми розвитку дитячого та молодіжного туризму розглядались в роботах багатьох вітчизняних та зарубіжних вчених. Так, в працях Блистів Т. досліджено мотивації учнів загальноосвітніх навчальних закладів до занять у центрах дитячо-юнацького туризму [1]. У роботах Топилко Н. проаналізовано зацікавленість учнів різними видами спортивно-оздоровчого туризму з метою зміцнення здоров'я та підвищення рухової активності [2]. В працях Троценко Т. Розглянуто туристсько-краєзнавчу діяльність як ефективний засіб морального виховання молодших школярів [3]. Дослідженнями Шипко А. встановлено, що підвиди соціокультурного туризму визначаються або за характерними ознаками змісту [4].

На сьогоднішній день основними напрямками у дитячому туризмі є:

- відпочинок та оздоровлення у вітчизняних і закордонних дитячих санаторіях, дитячих закладах оздоровлення цілорічної дії;

- відпочинок у таборах з тематичними програмами, спортивної направленості, релігійні;

- відпочинок з метою вивчення іноземної мови, ознайомлення 3 культурою іншого народу, як правило, європейського, (у дитячих центрах); 
- екскурсійні культурно-пізнавальні програми по Україні та за кордон, які організовуються для учнів навчальних закладів;

- активний спортивний туризм: піші походи, сплави на байдарках, велосипедний та кінний туризм;

- поїздки на фестивалі, концерти, до тематичних парків розваг.

Сьогодні існує багато пропозицій дитячих оздоровчих таборів бюджетного і дорогого сегменту як в Україні, так і за кордоном.

В Україні $є$ достатньо велика кількість таборів 3 різним спрямуванням підготовки та умовами розміщення, як бюджетної, так $\mathrm{i}$ високої цінової категорії.

Серед бюджетних дитячих таборів популярними на сьогодні $\epsilon$ Військово-патріотичний табір Азовець (м. Київ), Козацький табір Світанок (м. Дніпро), танцювальний табір MIXSTYLE DANCE CAMP с. Гута (Івано-Франківська обл.), дитячий табір Мрія (м. Бердянськ, Запорізька обл.) та інші.

Серед таборів високої цінової категорії з широким спектром послуг можна назвати табір Ух-ти Кемп (с. Славське, Львівської обл.), табір Eco Point Camp (с. Река, Мукачевський район, Закарпатська область.), табір Шоколад (смт. Сергіївка, Одеська область) та інші.

Дитячий та юнацький туризм допоможе краще пізнати свою країну, ознайомитись із пам'ятками історії, архітектури та культурою інших країн.

\section{Список бібліографічних посилань}

1. Блистів Т. Мотиваційні пріоритети школярів до занять у центрах дитячоюнацького туризму [Електронний ресурс] / Тарас Блистів // Спортивна наука України. - 2015. - № 1(65). - С. 70-75. - Режим доступу : http://sportscience.ldufk.edu.ua/index.php/snu/article/view/

2. Топилко Н. Проблеми активізації занять туризмом учнівської молоді / Надія Топилко, В. Семенюк // Проблеми активізації рекреаційно-оздоровчої діяльності населення : матеріали VIII Всеукр. наук.-практ. конф. 3 міжнар. участю. - Львів, 2012. - С. 288- 291.

3. Троценко Т. Туристсько-краєзнавча діяльність як ефективний засіб морального виховання молодших школярів / Тетяна Троценко // Спортивний вісник Придніпров’я. - 2010. - № 2. - С. 77-79.

4. Шипко А. Структура туризму учнівської молоді / А. Шипко // Актуальні проблеми юнацького спорту : матеріали VI Всеукр. наук.-прак. конф. - Херсон, 2008. - С. 276- 279. 